\title{
Comparative Study of Wear Characteristics and Material Composition Analysis of Different Types of Rotavator Blade
}

\author{
Rajat Arya $^{1}$, Raushan Kumar ${ }^{2}$ and R. N. Pateriya ${ }^{3}$ \\ Department of Farm Machinery and Power Engineering, College of Technology, \\ GBPUA\&T, Udham Singh Nagar, Uttarakhand 263145, India \\ *Corresponding author
}

\section{A B S T R A C T}

\section{Keywords}

Tillage Implement, wear analysis, material analysis, rotavator blade

\section{Article Info}

Accepted:

05April 2020

Available Online:

10 May 2020
Rotavator is an efficient tillage implement used for rapid bed preparation and is an energy and time efficient equipment for different soils compared to all other conventional tillage implements. The primary cause that limits the persistence of rotavator is wear of its blades. This paper was undertaken to study the material composition and wear characteristics of austempered ductile iron third edition rotavator blades which were developed by austempering heat process done over cast iron. The objective was carried out by means of elemental analysis and identification of wear pattern of rotavator blades with increase in operational time. The results indicated that the change in material composition was responsible for wear of rotavator blades. Iron and carbon content decreased from 84.33 and 5.30 $\%$ to 72.4 and $4.20 \%$ respectively. Weight loss of $140.2 \mathrm{~g}$ was observed in austempered ductile iron (Fe: $84.33 \%$, C: $5.30 \%$ ) rotavator blades after the operation period of 100 hours.

\section{Introduction}

Farm mechanization has been a key concern for our policy makers where overall level of mechanization is only about 40 to $45 \%$ in which contribution of mechanical and electrical power sources is almost about $90 \%$ of the total power. Improved farm machines and equipment's reduces the drudgery of operations and also increases the quality of work. Rotavator is tillage tool used for seed bed preparation and controlling of weed in arable field condition. It comprises of blades mounted on a flange which is fixed on a shaft, and the shaft is driven by PTO of a tractor through combination of differential gears and chain.

Rotavator facilitate rapid seedbed preparation and reduces the draft in comparison to the conventional tillage implements. It saves 20 to $25 \%$ of cost of operation, 30 to $35 \%$ of 
time of operation compared to tillage carried out by ploughs, harrows and cultivators. Rotavator is the most efficient means of transmitting engine power to soil in expense of minimum wheel slippage and major reduction in power losses occurring during transmission.

Despite of consuming high power, rotavator is energy efficient and time efficient equipment for different soils compared to all other conventional tillage implements.

(Yatsuk et al., 1971) reported that the material used in manufacturing of rotavator blades affect their useful life. L shaped blades are most suitable for Indian farming conditions reason being, it does not pulverize the soil too much. But still the wearing of blades takes place after certain hours (80-100 hours) of operation, which must be overcome to increase the service life of the blades.

Most frequent problem that occurs with rotavators are wearing of rotavator blades which increases the draft and energy requirement for working of rotavators.

Studies are being carried out on various material compositions of rotavator blades and one such material which has gained attention for manufacturing of rotavator blades is ADI (Austempered Ductile Iron) due to its exceptionally good blend of low cost, toughness, fatigue strength, and wear resistance (Rana, et al., 2016).

Cast iron is converted into ADI through an attractive thermal process known as austempering. Austempering of cast iron consists of three steps: austenitizing of the cast iron matrix, rapid cooling to the isothermal treatment temperature and isothermal treatment usually in the range of $250^{\circ} \mathrm{C}-450^{\circ} \mathrm{C}$. ADI $\left(3^{\text {rd }}\right.$ edition) rotavators blades are the newly developed blades fabricated at Central Mechanical Engineering Research Institute, Durgapur, West Bengal, India. Therefore, in ongoing activities of the advancement of rotavator blades the present study was carried out with the following objectives includes to study material composition of ADI ( $3^{\text {rd }}$ edition) rotavator blades. And to study wear characteristics of rotavator blades in actual field conditions.

\section{Materials and Methods}

In this paper, our main motive is to study the wear characteristics and material composition of ADI ( $3^{\text {rd }}$ edition) rotavator blades. The determination of material composition and wear pattern of rotavator blades were carried out for 100 hours of operation at a time interval of 10, 30, 50, 70, 90 and 100 hours.

\section{Selection of rotavator blade}

A survey was carried out with rotavator manufacturers/distributors and local spare part dealers for the availability of rotavator blades. Both imported and indegenous rotavator blades were available in the local market of different specifications and compositions.

During the survey it was noticed that the rotavators were usually mounted with Lshaped blades. The blades selected for the experiment were imported blade (Jumbo make in Italy), indegenous blade (Jay Bharat) and a new ADI $3^{\text {rd }}$ edition (Austempered Ductile Iron) rotavator blades which were the successor to ADI ( $1^{\text {st }}$ edition) and ADI $\left(2^{\text {nd }}\right.$ edition) rotavator blades fabricated at CSIRCentral Mechanical Engineering Research Institute, Durgapur, West Bengal, India.

\section{Specification of rotavator blades}

The dimensions of ADI ( $3^{\text {rd }}$ edition), Indigenous and Imported rotavator blades are 
shown in Fig. 1 (a,b,c) respectively. The parameters of blades are shown in Table 1.

\section{Surface characteristics of selected rotavator blades}

Surface characteristics of ADI ( $3^{\text {rd }}$ edition) rotavator blades was determined with the use of Scanning Electron Microscope (SEM). Electron microscope produces images of a sample by scanning the surface with a focused beam of electrons which interacts with atoms in the sample and produces various signals containing information about the surface topography and composition of the sample.

Elemental analysis and imaging of all the three selected rotavator blades were performed with the provision of Energy Dispersive Spectrometer (EDS) equipped in Scanning Electron Microscope. A beam of Xrays or high energy beam of charged particles (electrons or protons) were focused on the sample being studied.

For determining the surface characteristics of rotavator blade firstly a sample section of blade shown in Fig. 2 was cut in the size (40 $\mathrm{mm} \times 8 \mathrm{~mm} \times$ blade thickness) and then cleaned with acetone solution in order to remove all the impurities. After the sample was prepared it was inserted in the specimen chamber of SEM and was rigidly mounted on a holder known as specimen stub.

The SEM records automatically the elemental composition and surface morphology of the specimen sample in an attached computer shown in Fig 3. The surface morphology was acquired in the form of magnified image showing different chemical composition around the surface of the sample.

\section{Hardness of rotavator blades}

Rockwell hardness tester as shown in Fig. 4 was used to measure the hardness of all the rotavator blades used under experiment. For measuring the hardness of rotavator blades firstly the blades were cleaned and then kept on the anvil of tester. In order to elevate the blade up to the indenter point rotary wheel was rotated. Initially the rotary wheel was rotated for about three times for applying the minor loading of $10 \mathrm{~kg}$ on the blade for penetrating the surface finishing layer, after minor loading was applied the pointer was set on the scale dial at 100 for $\mathrm{C}$-scale. $\mathrm{F}$

urther the loading was done by pushing forward the load application lever for applying major load of $140 \mathrm{kgf}$ in C scale, when the pointer came to rest position the load application lever was pushed back. After the load applied was released the pointer rotated in reverse direction and came to rest, then the hardness number was directly noted from the scale.

\section{Selection of rotavator under study}

A rotavator available in the Farm Machinery and Power Engineering Department, of Govind Ballabh Pant University of Agriculture and Technology, Pantnagar, Udham Singh Nagar, Uttarakhand (India) as shown in Fig.5 was used for the study. Rotavator selected had an overall width of 2.1 meters, had a provision to mount $42 \mathrm{~L}$-shaped blades on 8 flanges and was also provided with depth adjustment with mounting brackets.

The rotavator was operated at a speed of 210 rpm driven by tractor PTO which was having a speed of $540 \pm 10 \mathrm{rpm}$. The study on material composition and wear characteristics of rotavator blades were carried out with three rotavator blades of different make considered as three treatments. These treatments are shown in Table2. The arrangement of rotavator bldades as different treatments are shown in Fig. 5 in which outer two flanges 
were mounted with three blades of three treatment T1, T2 and T3 each. While remaining six flanges were mounted with 36 blades with each treatment mounted twice in each flanges.

\section{Wear measurement of rotavator blades}

During the study, wear of rotavator blades was measured dimensionally as well as gravimetrically. The blades were allowed to run for almost 100 hours and wear was measured at an interval of each 20 hours. The procedures for measuring both gravimetric wear and dimensional wear are described below.

\section{Gravimetric wear of rotavator blades}

Gravimetric wear of rotavator blades provides reduction in weight of the blade material. Initially the weight of all rotavators blades of three different make was measured using an Electronic Balance (weighing range of 0 3.100 g) shown in Fig. 6 (a).

After each 20 hours of working, the blades were dismounted from the rotavator and were firstly washed in clean water and secondly in dilute acetone solution so that all impurities left in the blade surface were removed completely. The difference in initial weight and final weight of blade for total 100 hours of operation gave the cumulative wear of rotavator blade.

\section{Dimensional wear of rotavator blades}

Dimensional wear deals with the wear of rotavator blades with respect to its width and thickness. This was measured with the use of "Grid method", in which blade was divided along its length into 10 divisions of $2 \mathrm{~cm}$ each. An ordinary graph paper was pasted on inner side of the blade by aligning points of the blade and forming a grid of $2 \mathrm{~cm} \times 2 \mathrm{~cm}$, as shown in the Fig. 6 (b) Width of rotavator blade was measured at each marked points along the length of the blade with help of digital vernier calliper having least count of $0.01 \mathrm{~mm}$. The width was measured from $0^{\text {th }}$ point on the blade section upto $10^{\text {th }}$ point on the leg section. The widths of the blades were measured before the operation and after successive interval of $10,30,50,70,90$ and 100 hours.

Digital micrometer of least count $0.01 \mathrm{~mm}$ was used to measure the thickness of the blade. Thickness was measured at each grid point along the width of the blade and for compensating the thickness of graph paper a deduction of $0.07 \mathrm{~mm}$ from micrometer reading was made. The thickness of the blades were measured at all points before the starting of operation, and same procedure was followed after successive interval of 10,30 , 50, 70, 90 and 100 hours.

\section{Field evaluation parameters}

The field tests were conducted at E-20 field of Norman Borlaug Crop Research Centre of Govind Ballabh Pant University of Agriculture and Technology, Pantnagar, Udham Singh Nagar, Uttarakhand (India). All parameter associated with field evaluation of rotavator is given in Table 3 .

\section{Results and Discussion}

The outcomes of the study are presented and discussed in this part of paper. Which contains the elemental analysis as well as wear analysis of ADI ( $3{ }^{\text {rd }}$ edition) rotavator blades. The elemental analysis of these blades was done with elemental distribution on the surface of rotavator blades.

The wear analysis was carried out on gravimetric (weight) as well as on dimensional basis. 


\section{Surface characteristics of selected rotavator blades}

Surface characteristics of ADI ( $3^{\text {rd }}$ edition), Indegenous and Imported rotavator blades were obtained with the use of Scanning Electron Microscope (SEM). Top surface of the blade section was the area where imaging and chemical analysis were performed. Elemental analysis was done twice, once before the operation started and again after the run of 100 hours. It was observed that carbon content in treatment $\mathrm{T} 1$ (ADI $3^{\text {rd }}$ edition) was maximum among all the three treatments, which gave it an extra edge in increasing its strength. In treatment T1 Iron (Fe) content was reduced from $84.33 \%$ to $72.4 \%$ and carbon content was reduced to $4.02 \%$. Also unnormalised concentration in weight percent was reduced from $100.00 \%$ to $85.91 \%$ at 0 hour and 100 hour run of rotavator blades. In treatment T2 (Indigenous) after 100 hours, in which Iron (Fe) content was reduced from $92.61 \%$ to 64 $\%$ and carbon content was reduced to $1.12 \%$. Its unnormalised concentration in weight percent was reduced from $100.88 \%$ to 74.43 $\%$. Change in elemental distribution of treatment T3 (Imported) after 100 hours, in which Iron $(\mathrm{Fe})$ content was reduced from $98.10 \%$ to $68.12 \%$ and carbon was reduced to $1.01 \%$. Its unnormalised concentration in weight percent was reduced from $103.49 \%$ to $79.21 \%$.

The concentration in weight after 100 hours of operation was minimum for treatment $\mathrm{T} 2$ $(74.43 \%)$, followed by treatment T3 $(79.21 \%)$ and was maximum for treatment $\mathrm{T} 1$ $(85.91 \%)$. Since the reduction in weight concentration after 100 hours of operation was minimum for treatment $\mathrm{T} 1$ (ADI $3^{\text {rd }}$ edition), wear characteristics were affected the least for ADI ( $3^{\text {rd }}$ edition) rotavator blades in comparison with other types of rotavator blades.

\section{Imaging of rotavator blades}

On the basis of surface analysis of rotavator blades, spectrum was obtained and imaging of rotavator blades was done which is presented from Fig. 7-9. From the study it was found that percentage of elements on the blade surface varied, also with increase in working hours there was a significant decrease or increase in percentage of various elements. Therefore, indicating that the surface characteristics of blades varied strongly affecting the wear characteristics of rotavator blades.

\section{Identification of wear pattern of blades}

Wear pattern of ADI ( $3^{\text {rd }}$ edition), Indigenous and Imported rotavator blades were studied by observing the reduction in weight of each rotavator blades during the time interval of $10,30,50,70,90$ and 100 hours. Wear pattern of blades were identified by measuring the reduction in their dimensions (width and thickness) at different points marked on the graph paper pasted on blade surface at time interval of $10,30,50,70,90$ and 100 hours.

\section{Gravimetric wear of rotavator blades}

The average of ten rotavator of each treatment T1 (ADI $3^{\text {rd }}$ edition), T2 (Indigenous) and T3 (Imported) were taken for measurement of weight loss. Initial average weight, cumulative weight loss and gravimetric wear rate of all three treatments are shown in Table 4.

Data from Table 4 revealed that minimum weight loss of $140.2 \mathrm{~g}$ was observed in treatment T1 (ADI $3^{\text {rd }}$ edition) followed by weight loss of $159.21 \mathrm{~g}$ observed in treatment T3 (Imported), whereas the maximum weight loss of $219.68 \mathrm{~g}$ was recorded in treatment $\mathrm{T} 2$ (Indigenous) after 100 hours of actual field 
operation. Table 4 also indicates that with increase in working hours the cumulative weight loss due to wear increases.

The result shows that, the Treatment T1 (ADI $3^{\text {rd }}$ edition) gave minimum gravimetric wear loss followed by treatment T3 (Imported) and the maximum wear loss was obtained by treatment T2 (Indigenous) due to poor resistance to abrasion and impact. The overall results of gravimetric wear of blades has been shown in Table 5, which indicated that from gravimetric point of view, T1 (ADI $3^{\text {rd }}$ edition) was found to be the best treatment.

Rockwell hardness tester used for measuring the hardness of rotavator blades gave the result of treatment $\mathrm{T} 1$ having hardness of 63.31 HRC, treatment T2 having hardness of 58.62 HRC, and treatment T3 having hardness of 60.31 HRC. Being material with the highest hardness number, treatment $\mathrm{T} 1$ was considered having more strength in comparison with the other two treatments.

\section{Dimensional wear of rotavator blades}

Results of dimensional wear was obtained with respect to width and thickness for treatments T1 (ADI $3^{\text {rd }}$ edition), T2 (Indigenous), and T3 (Imported).

\section{Reduction in width of selected rotavator blades}

Table 6 shows the average width loss of treatments T1, T2 and T3 at different operation hours of 10, 30, 50, 70, 90 and 100 at different points. The data revealed that with increase in operation time, average width at all points along the length of the blade decreases.
The data from Table 6 revealed that the wear loss in width after the operation of 100 hours at position $0 \mathrm{~mm}$ was minimum for treatment T1 (34.25 mm) followed by treatment T3 $(36.74 \mathrm{~mm})$ and $\mathrm{T} 2(49.87 \mathrm{~mm})$, at position $120 \mathrm{~mm}$ was minimum for treatment $\mathrm{T} 1$ $(18.56 \mathrm{~mm})$ followed by treatment T3 (19.25 $\mathrm{mm}$ ) and treatment $\mathrm{T} 2(27.63 \mathrm{~mm})$, and at position $200 \mathrm{~mm}$ was minimum for treatment T1 $(3.11 \mathrm{~mm})$ followed by treatment T3 $(9.16$ $\mathrm{mm})$ and treatment T2 $(15.18 \mathrm{~mm})$.

\section{Reduction in thickness of selected rotavator blades}

The average wear loss in thickness of rotavator blades after the operation of 100 hours in field conditions for treatments T1, T2 and $\mathrm{T} 3$ has been recorded. From the data recorded it was observed that reduction in thickness for all three treatments were maximum at blade section $\left(0^{\text {th }}\right.$ point $)$, followed by bent section ( $6^{\text {th }}$ point) and leg section ( $9^{\text {th }}$ point $)$.

In comparison, at blade section $(0,0)$ minimum reduction in thickness was for treatment $\mathrm{T} 1 \quad(2.29 \mathrm{~mm})$, followed by treatment T3 $(3.29 \mathrm{~mm})$ and treatment $\mathrm{T} 2$ $(3.59 \mathrm{~mm})$. At bent section $(120,0)$ minimum reduction in thickness was for treatment $\mathrm{T} 1$ $(2.12 \mathrm{~mm})$, followed by treatment T3 $(2.85$ $\mathrm{mm})$ and treatment $\mathrm{T} 2(3.45 \mathrm{~mm})$.

Whereas, at leg section $(180,0)$ minimum reduction in thickness was for treatment $\mathrm{T} 1$ $(1.74 \mathrm{~mm})$, followed by treatment T3 (1.91 $\mathrm{mm}$ ) and treatment T2 ( $2.85 \mathrm{~mm})$. The data for average thickness loss for all blades is provided from Table 7. 
Table.1 Parameters of rotavator blades

\begin{tabular}{|c|c|c|c|}
\hline Parameters & $\begin{array}{c}\text { ADI (3 } \\
\text { edition) }\end{array}$ & Indigenous & Imported \\
\hline Blade span, mm & 86 & 85 & 85 \\
\hline Effective vertical length, mm & 160 & 155 & 160 \\
\hline Blade cutting width, mm & 140 & 135 & 138 \\
\hline Blade thickness, mm & 7.6 & 7.2 & 6 \\
\hline Sweep back angle & $3^{0}$ & $5^{\circ}$ & $5^{\circ}$ \\
\hline Blade section width, mm & 76 & 80 & 70 \\
\hline Hole diameter, $\mathbf{m m}$ & 15 & 15 & 15 \\
\hline
\end{tabular}

Table.2 Experimental treatments of rotavator blades

\begin{tabular}{|l|l|c|}
\hline Treatments & Type of blade & No. of blades \\
\hline T1 & ADI ( ${ }^{\text {rd }}$ edition) & 14 \\
\hline T2 & Indegenous (Jay Bharat) & 14 \\
\hline T3 & Imported (Jumbo make) & 14 \\
\hline
\end{tabular}

Table.3 Field evaluation parameters

\begin{tabular}{|l|l|}
\hline Parameters & Values \\
\hline Forward speed of prime mover & $3.50-4.50 \mathrm{~km} / \mathrm{h}$ \\
\hline Speed of rotor shaft & $210 \mathrm{rpm}$ \\
\hline Depth of cut & $80-100 \mathrm{~mm}$ \\
\hline Width of cut & $1.86 \mathrm{~m}$ \\
\hline Draft of rotavator & $3305 \mathrm{~N}$ \\
\hline Bulk density & $1.541 \mathrm{~g} / \mathrm{cc}$ \\
\hline Moisture content & $15-18 \%$ \\
\hline Actual field capacity & $0.40 \mathrm{ha} / \mathrm{h}$ \\
\hline Theoritical field capacity & $0.65 \mathrm{ha} / \mathrm{h}$ \\
\hline
\end{tabular}

Table.4 Gravimetric wear analysis of the blades of different treatment at different working hours

\begin{tabular}{|c|c|c|c|c|c|c|c|c|c|}
\hline \multirow[t]{3}{*}{$\begin{array}{l}\text { Working } \\
\text { hours }\end{array}$} & \multirow{2}{*}{\multicolumn{3}{|c|}{ Average weight of blades, $g$}} & \multirow{2}{*}{\multicolumn{3}{|c|}{$\begin{array}{c}\text { Cumulative weight loss of } \\
\text { blades, } g \\
\text { Treatments }\end{array}$}} & \multicolumn{3}{|c|}{ Gravimetric wear rate, $\mathrm{g} / \mathrm{h}$} \\
\hline & & & & & & & & & \\
\hline & T1 & T2 & T3 & T1 & $\mathbf{T 2}$ & T3 & T1 & $\mathbf{T} 2$ & T3 \\
\hline $\mathbf{0}$ & 1165 & 1127.88 & 1041.81 & 0 & 0 & 0 & 0 & 0 & 0 \\
\hline 10 & 1157.2 & 1120.7 & 1031.7 & 7.8 & 7.18 & 10.11 & 0.78 & 0.718 & 1.011 \\
\hline 30 & 1135.8 & 1088.7 & 1006.77 & 29.2 & 39.18 & 35.04 & 0.973 & 1.306 & 1.168 \\
\hline 50 & 1115.25 & 1035.2 & 970.8 & 49.75 & 92.68 & 71.01 & 0.995 & 1.854 & 1.42 \\
\hline 70 & 1087.02 & 989.63 & 939.08 & 77.98 & 138.25 & 102.73 & 1.114 & 1.97 & 1.476 \\
\hline 90 & 1062.5 & 943.2 & 905.98 & 102.5 & 184.68 & 135.83 & 1.139 & 2.052 & 1.509 \\
\hline 100 & 1024.8 & 908.2 & 882.6 & 140.2 & 219.68 & 159.21 & 1.402 & 2.197 & 1.592 \\
\hline
\end{tabular}


Table.5 Overall results of gravimetric wear of rotavator blades

\begin{tabular}{|c|l|l|}
\hline Result after 100 hours & Minimum & Maximum \\
\hline Weight loss of blade & $140.2 \mathrm{~g}\left[\mathrm{~T} 1\right.$ (ADI $3^{\text {rd }}$ edition) $]$ & $219.68 \mathrm{~g}$ [T2 (Indigenous)] \\
\hline Overall wear rate of blade & $\begin{array}{l}0.915 \mathrm{~g} / \mathrm{h}\left[\mathrm{T} 1 \text { (ADI } 3^{\text {rd }}\right. \\
\text { edition) }\end{array}$ & $1.442 \mathrm{~g} / \mathrm{h}[\mathrm{T} 2$ (Indigenous)] \\
\hline
\end{tabular}

Table.6 Average width loss of the blades at different point at different working hour

\begin{tabular}{|c|c|c|c|c|c|c|c|c|c|c|c|c|}
\hline \multirow[b]{3}{*}{ Treatments } & \multirow[b]{3}{*}{$\begin{array}{l}\text { Working } \\
\text { Hours, h }\end{array}$} & \multicolumn{11}{|c|}{ Average width loss of the blade, mm } \\
\hline & & \multicolumn{11}{|c|}{ Points along the length of the blade, mm } \\
\hline & & 0 & 20 & 40 & 60 & 80 & 100 & 120 & 140 & 160 & 180 & 200 \\
\hline \multirow[t]{7}{*}{ T1 } & 0 & 0 & 0 & 0 & 0 & 0 & 0 & 0 & 0 & 0 & 0 & 0 \\
\hline & 10 & 1.3 & 0.74 & 0.62 & 0.33 & 0.29 & 0.25 & 0.21 & 0.19 & 0.11 & 0.11 & 0.11 \\
\hline & 30 & 5.88 & 4.92 & 4.15 & 3.75 & 2.91 & 2.01 & 1.59 & 1.13 & 1.09 & 1.01 & 0.91 \\
\hline & 50 & 10.12 & 8.42 & 7.63 & 6.21 & 4.10 & 2.72 & 2.01 & 1.93 & 1.23 & 1.05 & 1.09 \\
\hline & 70 & 12.81 & 11.5 & 9.81 & 8.52 & 6.23 & 4.13 & 3.11 & 2.56 & 1.51 & 1.11 & 1.10 \\
\hline & 90 & 25.23 & 24.83 & 22.12 & 19.81 & 15.21 & 12.12 & 10.23 & 8.11 & 6.81 & 2.97 & 2.55 \\
\hline & 100 & 34.25 & 33.16 & 31.91 & 29.11 & 27.61 & 23.45 & 18.56 & 15.23 & 12.13 & 6.23 & 3.11 \\
\hline \multirow[t]{7}{*}{$\mathbf{T} 2$} & O & 0 & 0 & 0 & 0 & 0 & 0 & 0 & 0 & 0 & 0 & 0 \\
\hline & 10 & 2.9 & 2.3 & 1.8 & 1.32 & 1.01 & 0.61 & 0.39 & 0.26 & 0.18 & 0.10 & 0.03 \\
\hline & 30 & 11.01 & 7.24 & 6.13 & 4.01 & 3.23 & 2.91 & 1.86 & 1.72 & 1.59 & 1.29 & 0.99 \\
\hline & 50 & 17.34 & 15.68 & 13.23 & 11.35 & 9.25 & 7.11 & 5.28 & 3.52 & 2.35 & 1.6 & 1.26 \\
\hline & 70 & 27.91 & 24.21 & 21.67 & 17.27 & 13.23 & 11.26 & 9.11 & 7.26 & 5.21 & 3.67 & 2.45 \\
\hline & 90 & 40.48 & 36.14 & 32.12 & 29.28 & 23.3 & 18.53 & 15.92 & 11.63 & 9.83 & 7.81 & 5.88 \\
\hline & 100 & 49.87 & 47.28 & 44.91 & 40.73 & 35.91 & 31.06 & 27.63 & 24.23 & 21.6 & 18.64 & 15.18 \\
\hline \multirow[t]{7}{*}{ T3 } & 0 & 0 & 0 & 0 & 0 & 0 & 0 & 0 & 0 & 0 & 0 & 0 \\
\hline & 10 & 1.67 & 0.70 & 0.58 & 0.25 & 0.21 & 0.17 & 0.13 & 0.09 & 0.07 & 0.05 & 0.02 \\
\hline & 30 & 6.67 & 5.55 & 4.95 & 3.12 & 2.13 & 2.01 & 1.86 & 1.71 & 1.67 & 1.31 & 1.01 \\
\hline & 50 & 11.39 & 8.91 & 7.83 & 5.81 & 3.71 & 2.13 & 2.09 & 1.89 & 1.74 & 1.68 & 1.25 \\
\hline & 70 & 18.17 & 16.83 & 14.33 & 12.26 & 10.13 & 6.58 & 4.23 & 2.98 & 2.45 & 2.12 & 1.91 \\
\hline & 90 & 26.17 & 25.11 & 22.26 & 20.05 & 15.12 & 10.31 & 8.16 & 7.39 & 6.85 & 5.96 & 3.98 \\
\hline & 100 & 36.74 & 34.26 & 31.91 & 28.88 & 26.62 & 21.22 & 19.25 & 17.11 & 14.21 & 11.83 & 9.16 \\
\hline
\end{tabular}

Table.7 Average blade thickness loss after 100 hour run at different point

\begin{tabular}{|c|c|c|c|}
\hline \multirow{2}{*}{ Points } & \multicolumn{3}{|c|}{ Average thickness loss of blade, mm } \\
\cline { 2 - 4 } & T1 & T2 & T3 \\
\hline $\mathbf{0}^{\text {th }}(\mathbf{0} \mathbf{~ m m})$ & 2.29 & 3.59 & 3.29 \\
\hline $\mathbf{6}^{\text {th }}(\mathbf{1 2 0} \mathbf{~ m m})$ & 2.12 & 3.45 & 2.85 \\
\hline $\left.\mathbf{9}^{\text {th }} \mathbf{( 1 8 0} \mathbf{~ m m}\right)$ & 1.74 & 2.32 & 1.91 \\
\hline
\end{tabular}




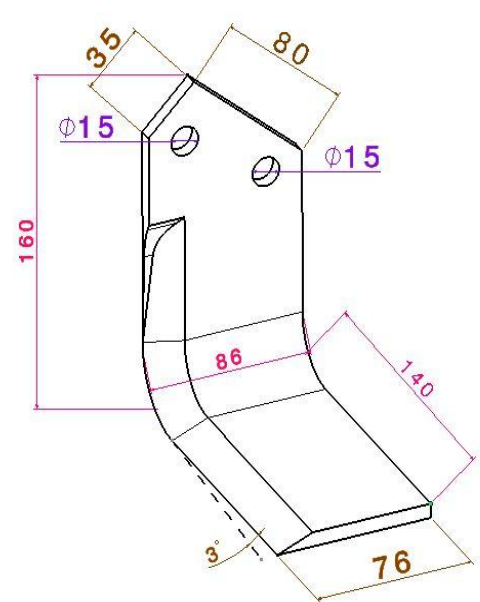

(a)

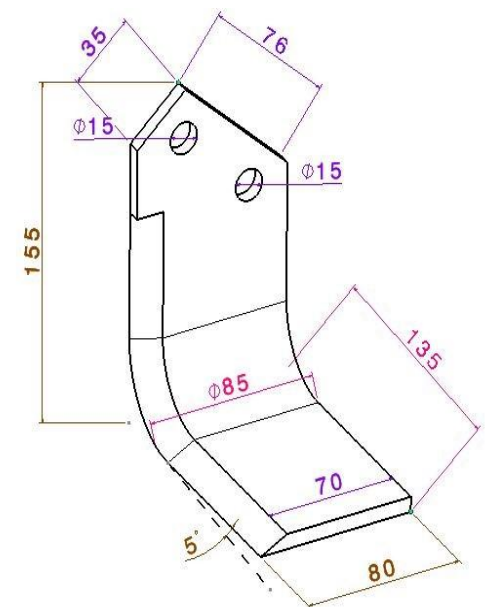

(b)

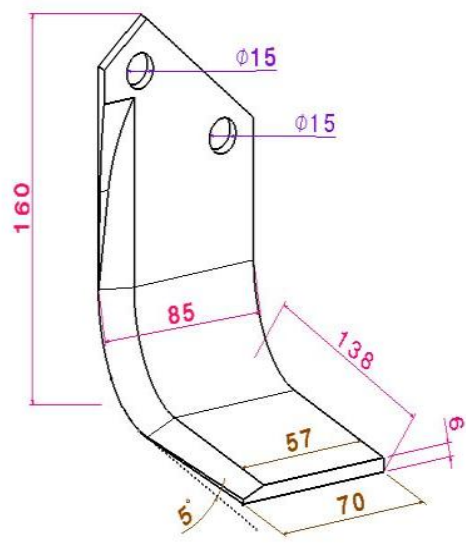

(c)

Fig.1 Dimensions of selected rotavator blades

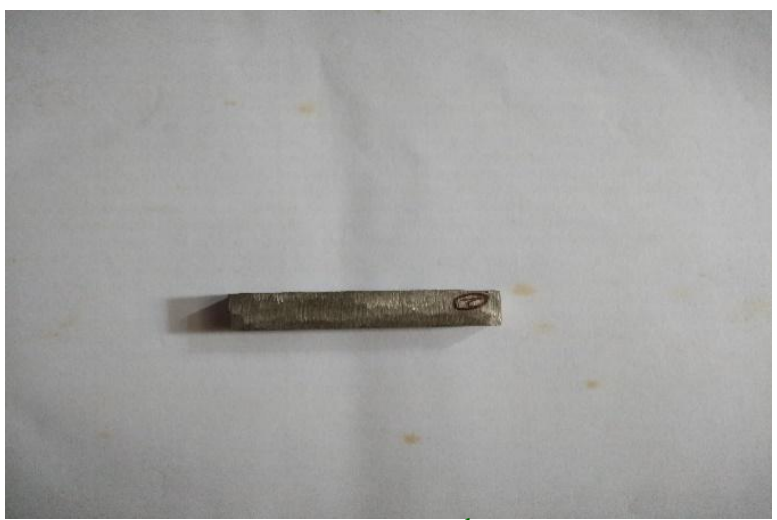

Fig.2 Sample section of ADI ( $3^{\text {rd }}$ edition) rotavtor blade
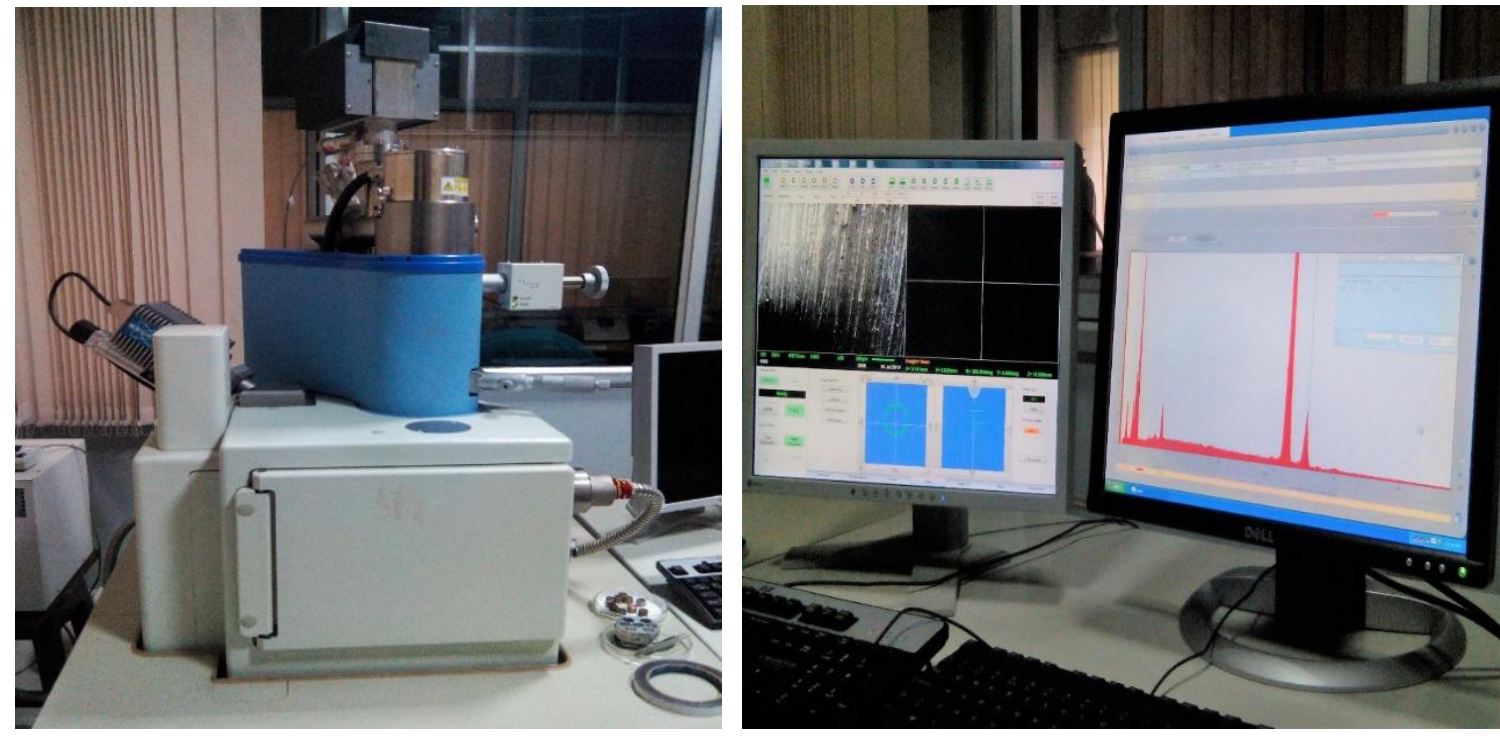

Fig.3 Scanning electron microscope with attached computer 

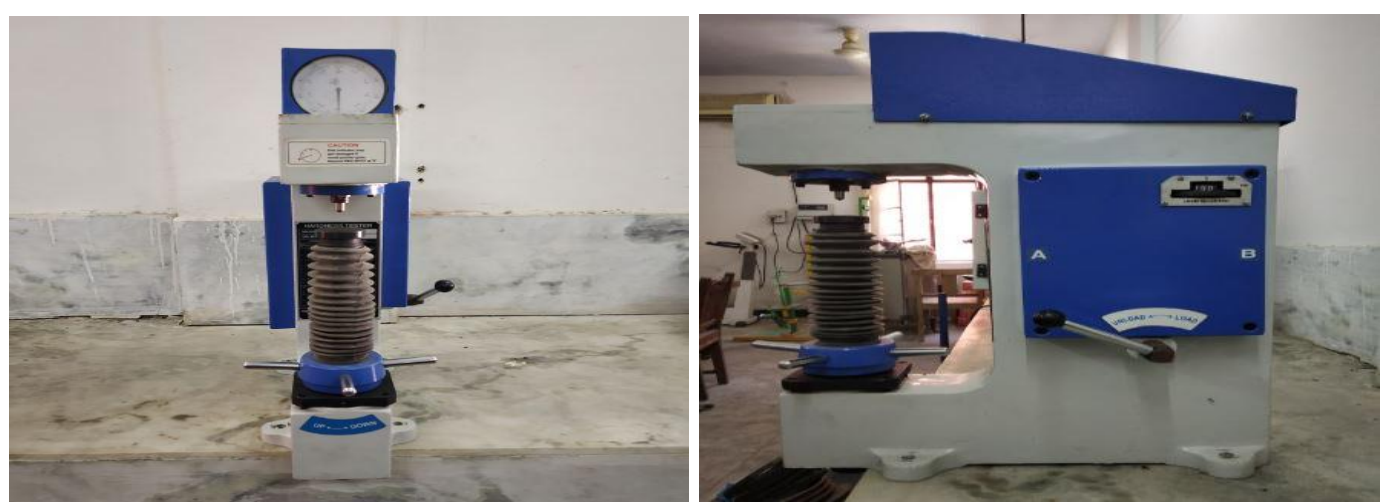

Fig.4 Rockwell hardness tester

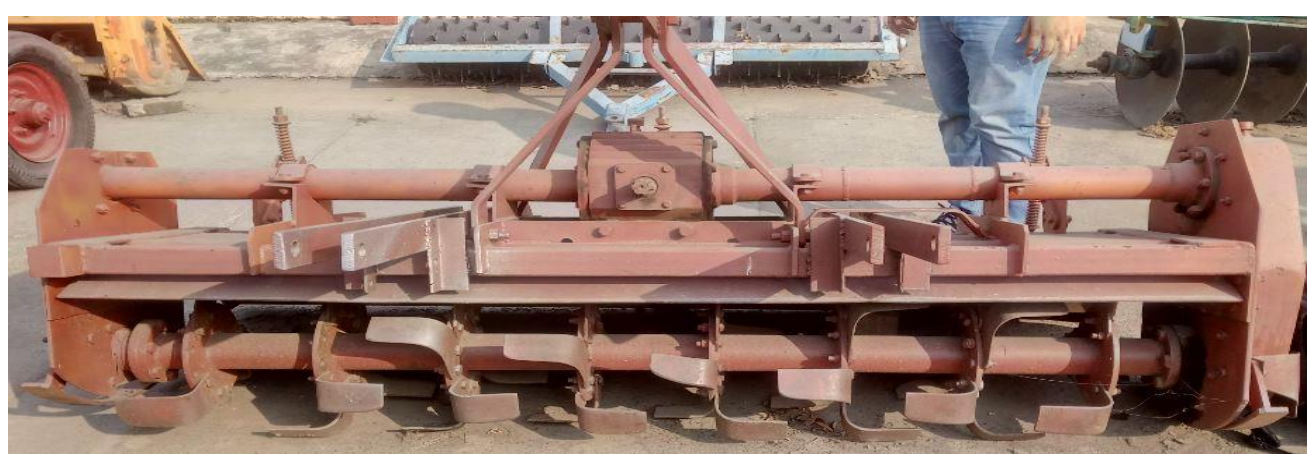

Fig.5 Rotavator with 8 flange and width of $210 \mathrm{~cm}$

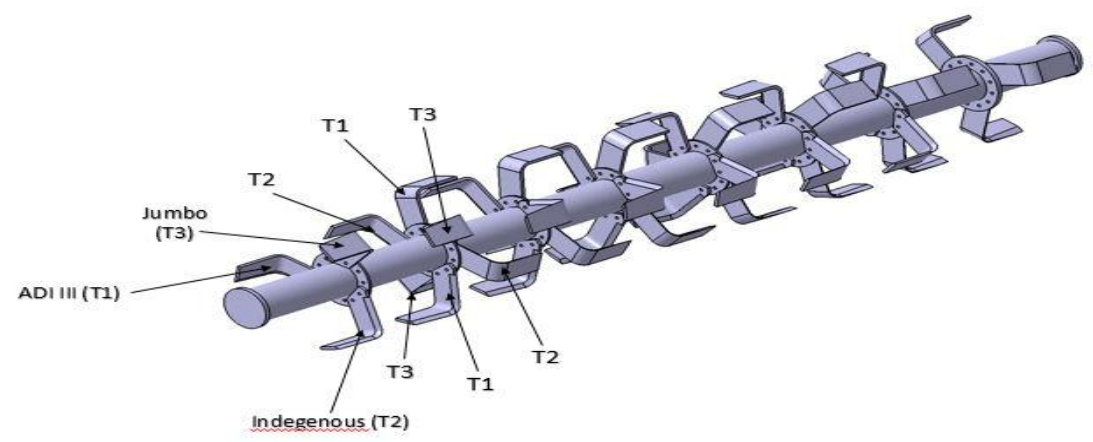

Fig.5 Arrangement of rotavator blades on rotor shaft

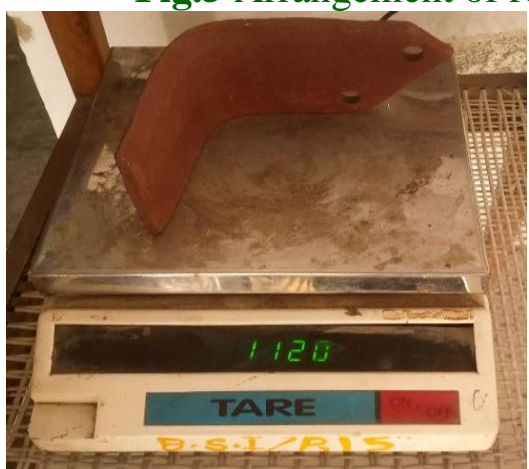

(a)

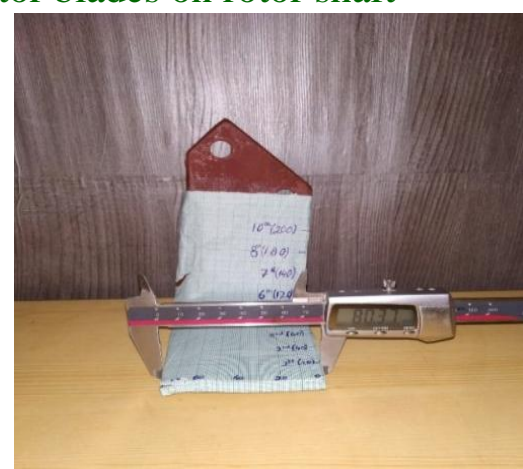

(b)

Fig.6 Gravimetrical and Dimensional measurement of blade 


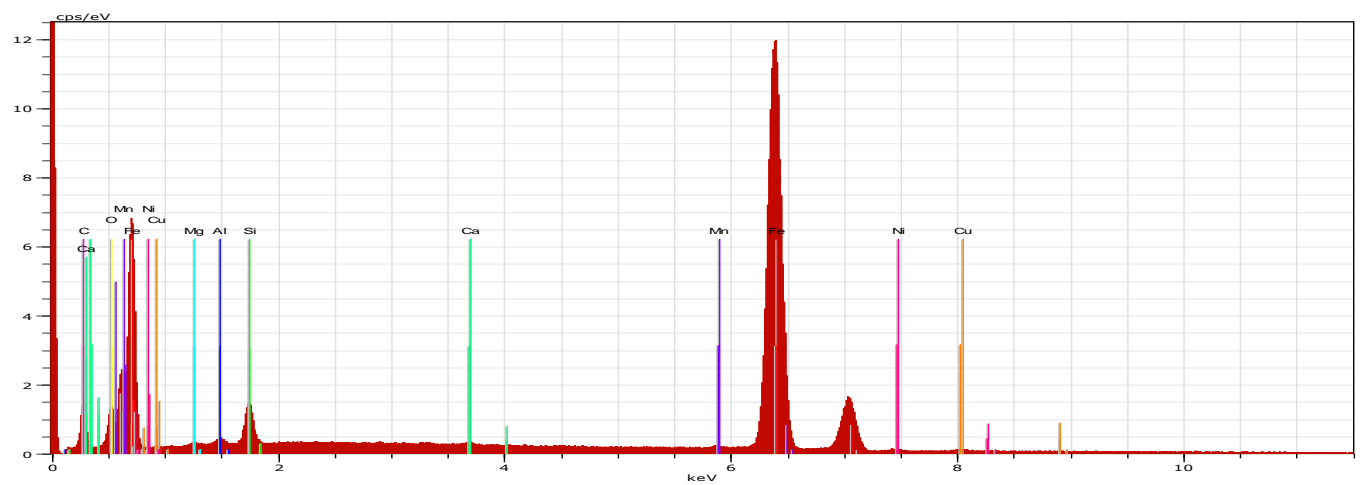

Fig.7 Spectrum of ADI ( $3{ }^{\text {rd }}$ edition) rotavator blade at 0 hour

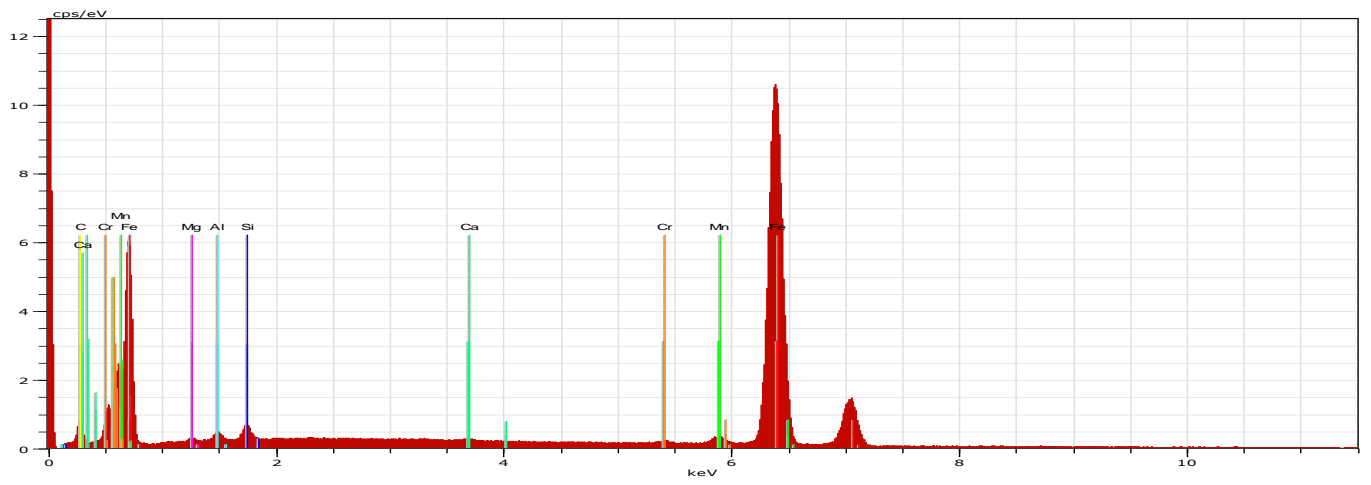

Fig.8 Spectrum of Indegenous rotavator blade at 0 hour

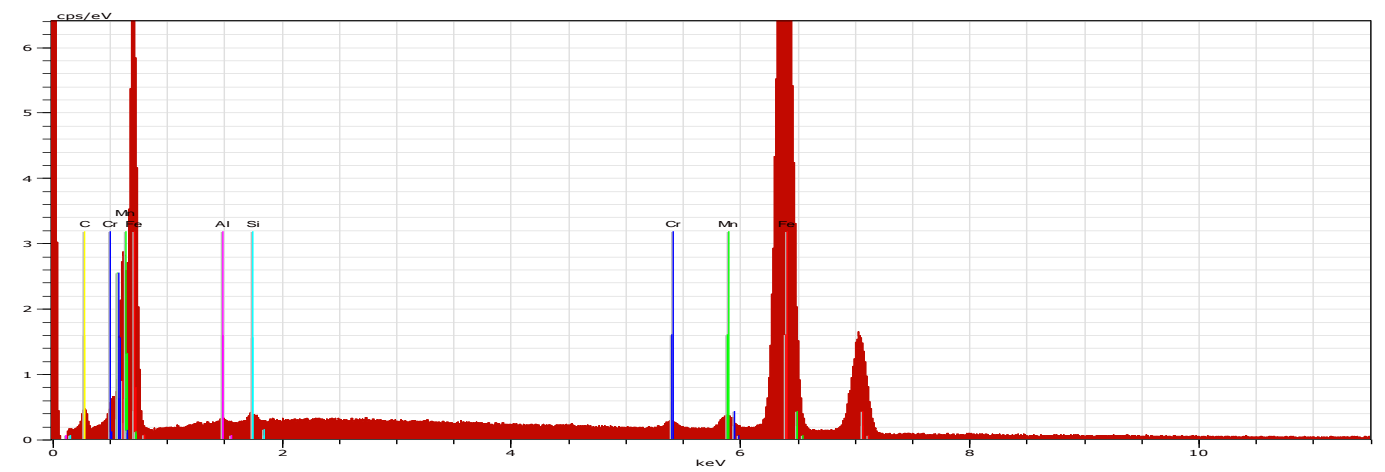

Fig.9 Spectrum of Imported (Jumbo make) rotavator blade at 0 hour

Rotavator saves time, cost and energy of operation and provides higher quality of work as compared to other tillage implements. Despite of consuming high power, rotavator is an energy efficient and time efficient equipment for different soils compared to all other conventional tillage implements. But due to the rapid wear of rotavator blades the use of rotavator becomes restrictive for the farmers.
The surface characteristics of rotavator blades revealed that chemical composition of blades varied with increasing working hours. Carbon content responsible for the hardeneabilty of rotavator blades was maximum in treatment T1 ADI $\left(3^{\text {rd }}\right.$ edition) with $5.30 \%$, and minimum for treatment T3 (Imported blade) with 2.31 $\%$.

The identification of wear pattern revealed 
that cutting edge of blade section was most prone to wear. It was evident that with increase in working hours the weight of rotavator blade decreases. Minimum weight loss of $140.2 \mathrm{~g}$ was observed in treatment $\mathrm{T} 1$ (ADI $3^{\text {rd }}$ edition) followed by $159.21 \mathrm{~g}$ in treatment T3 (Imported), whereas the maximum weight loss of $219.68 \mathrm{~g}$ was recorded in treatment T2 (Indigenous) after 100 hours of actual field operation.

It was observed that reduction in thickness for all three treatments were maximum at blade section $\left(0^{\text {th }}\right.$ point $)$, followed by bent section ( $6^{\text {th }}$ point) and leg section $\left(10^{\text {th }}\right.$ point $)$. In comparison, at blade section $(0,0)$ minimum reduction of thickness was for treatment T1 (2.29 $\mathrm{mm})$, followed by treatment T3 (3.29 $\mathrm{mm})$ and treatment $\mathrm{T} 2(3.59 \mathrm{~mm})$. At bent section $(120,0)$ minimum reduction in thickness was for treatment T1 $(2.12 \mathrm{~mm})$, followed by treatment T3 $(2.85 \mathrm{~mm})$ and treatment T2 $(3.45$ $\mathrm{mm})$. Whereas, at leg section $(180,0)$ minimum reduction in thickness was for treatment $\mathrm{T} 1(1.74 \mathrm{~mm})$, followed by treatment $\mathrm{T} 3(1.91 \mathrm{~mm})$ and treatment $\mathrm{T} 2(2.85 \mathrm{~mm})$.

Therefore, after going through all the observations it can be concluded that ADI $\left(3^{\text {rd }}\right.$ edition) rotavator blades observed least wear loss in comparison to other rotavator blades. Wear pattern of ADI ( $3^{\text {rd }}$ edition) rotavator blades was uniform in nature and also has the least wear rate in comparison with other rotavator blades.

\section{References}

Rana, M., \& Pateriya, R. N. (2016). A study on ADI rotavator blades. Res. Environ. Life Sci. 9(7) 871-874.

Yatsuk, E. P., 1981. Rotary soil working machines: construction, calculation and design, Amerind publication, New Delhi, India.

\section{How to cite this article:}

Rajat Arya, Raushan Kumar and Pateriya. R. N. 2020. Comparative Study of Wear Characteristics and Material Composition Analysis of Different Types of Rotavator Blade. Int.J.Curr.Microbiol.App.Sci. 9(05): 390-401. doi: https://doi.org/10.20546/ijcmas.2020.905.044 